\title{
Lack of association between toll like receptor-2 \& toll like receptor-4 gene polymorphisms and Iranian asthmatics risk or features
}

Hamid Bahrami' ${ }^{1}$ Saeed Daneshmandi' ${ }^{1}$ Hasan Heidarnazhad ${ }^{2}$ and Ali Akbar Pourfathollah ${ }^{1 *}$

*Correspondence: pourfa@modares.ac.ir

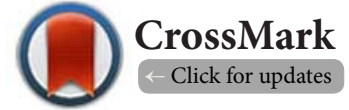

'Department of Immunology, Tarbiat Modares University, Faculty of Medical Sciences, Tehran, Iran.

${ }^{2}$ TB and Lung disease Research Cancer, NRITLD, Masih Daneshvari Hospital, Shahid Beheshti University of Medical Sciences, Tehran, Iran.

\begin{abstract}
Introduction: Asthma as chronic inflammatory airway disease is considered to be the most common chronic disease that is involving genetic and environmental factors. Toll like receptors (TLRs) and other inflammatory mediators are important in modulation of inflammation. In this study we evaluated the role of TLR2 Arg753Gln and TLR4 Asp299Gly polymorphisms in the asthma susceptibility, progress, control levels and lung functions in Iranian subjects.

Methods: On 99 asthmatic patients and 120 normal subjects, TLR2 Arg753Gln and TLR4 Asp299Gly polymorphism were evaluated by PCR-RFLP method recruiting Msp1 and Nco1 restriction enzymes, respectively. IgE serum levels by ELISA technique were determined and asthma diagnosis, treatment and control levels were considered using standard schemes and criteria.

Results: Our results indicated that the genotype and allele frequencies of the TLR2 Arg753Gln and TLR4 Asp299Gly polymorphisms were not significantly different between control subjects and asthmatics $(p>0.05)$ or even in asthma features such as IgE levels, asthma history and pulmonary factors ( $\mathrm{p}>0.05)$.

Conclusions: Meanwhile some previous studies indicated TLRs and their polymorphisms role in asthma incidence and features, our data demonstrated that TLR2 Arg753Gln and TLR4 Asp299Gly gene variants were not risk factor of asthma or its features in Iranian patients. Genetic complexity, ethnicity, influence of other genes or polymorphisms may overcome these polymorphisms in our asthmatics.
\end{abstract}

Keywords: Asthma, TLR2, TLR4, polymorphism, RFLP-PCR

\section{Introduction}

Asthma is a complex and chronic disease in which allergeninduced inflammatory processes in the airways contribute to the development of symptoms, such as wheezing, cough, dyspnea and breathlessness [1]. Asthma is considered to be the most common chronic disease and the leading cause of hospitalization in schoolchildren $[2,3]$. Control of asthma and response to medication is different in patients, and different asthmatics show various levels of asthma severity and progress which would depend on multiple factors especially genetic composition of patients. The need for management of medication and control of asthma make us improve our knowledge about pathogenesis of asthma and role of different elements that contribute to airway inflammation or influence signs and symptoms $[4,5]$. Asthma is believed to be a complex disorder involving genetic and environmental factors [6]. Many allergens and environmental microorganisms have pattern molecules on their surfaces, and these molecules interact with pattern-recognition receptors, which are part of the innate immune system. Among the known pattern-recognition receptors for microbial products, toll-like receptors (TLRs) are an evolutionarily conserved group of molecules expressed in antigen-presenting cells and epithelial cells [7]. TLRs recognize microbial patterns and play a crucial role in linking innate and adaptive immunity inducing a proinflammatory immune response that may counterbalance allergic diathesis. They initiate intracellular signaling pathways, bind to downstream protein kinases, induce activation of transcription factors, and initiate transcription of inflammatory cytokines and other host response elements [8]. Among TLRs, TLR4 recognizes lipopolysaccharide, a cell wall component of 
Bahrami et al. HOAJ Biology 2014,

gram-negative bacteria. In contrast, TLR2 recognizes a wide spectrum of Patogen Associated Molecular Patterns(PAMPs) such as membrane components of Gram-positive and -negative bacterial cell wall, mycoplasma, mycobacteria, yeast and parasites [9]. A study showed the alterations in intestinal microflora balance promoted the maturity of Dendritic Cells(DCs) and raised the expressions of TLR2 and TLR4 on DCs in allergic mouse lung [10]. TLR2 signaling has been shown to induce Treg cell expansion accompanied by a loss of suppressive activity in vitro and in vivo [11]. A study mentioned protective effects of TLR2 polymorphisms on lung function among workers in swine operations and the possibility of its protective role in airway disease in individuals exposed to gram-positive organisms in the inhaled airborne dust [12]. In TLR4 deficient mice allergen-induced eczema were exacerbated and also Increased allergen-induced skin levels of innate (IL-1 $\beta$, TNF- $\alpha$, and CXCL2) and Th17 genes (IL-17A and IL-17F) were observed in TLR4-deficient mice compared with wild-type mice [13]. All of these findings support role of TLRs in asthma susceptibility or asthma features as they determine type, severity and outcomes of asthma pathogenesis. On the other hand, the amounts of TLR synthesis in the cells or their functions are determined by some polymorphisms in their genes. As a result, polymorphisms in TLRs genes might determine susceptibility or progress of disease and degree of asthma control. With regards to the proposed role TLRs in asthma, in this study we analyzed the genetic variants of TLR2 Arg753GIn, and TLR4 Asp299Gly in Iranian asthmatic patients to evaluate role of these polymorphisms in asthma susceptibility, progress, control and lung functions.

\section{Materials and methods Study populations}

In this study, 99 unrelated adult patients ( 28 male and 71 female and mean \pm SD age of $44.15 \pm 13.06$ years) (Table 1 ), whose asthma was defined according to the criteria of the Global Initiative for Asthma (GINA) [14] were enrolled. Clinical history, physical examination, and pulmonary function test (PFT) in a standard fashion were assessed for all subjects. Asthmatics have had treatment in a standard scheme as inhaled corticosteroids and/or bronchodilator when necessary, and the asthmatic patients were subdivided into two control groups based on American Thoracic Society criteria [15] as Asthma Control Tests (ACT). Smoking history of more than 10 pack-years, presence of parasitic infection, and pregnancy or breastfeeding were exclusion criteria. A total of 120 healthy volunteers were recruited from the general population. Controls had to meet the following criteria: good health status and matched with the cases for age, gender, and area of residence, no respiratory symptoms or history of asthma and allergy. Questionnaire are designed and all the asthmatic patients Fill In and The study protocol was approved by the ethics committee at our institution, and written informed consent was obtained from all participants.
Table 1. Study populations.

\begin{tabular}{lll}
\hline & Asthmatic group & Control group \\
\hline number & 99 & 120 \\
Female/male & $71 / 28$ & $83 / 37$ \\
mean \pm SD of age & $44.15 \pm 13.06$ years & $46.6 \pm 14$ \\
Have a clinical asthmatic symptoms & have & Not have \\
\hline
\end{tabular}

\section{Total serum IgE measurements}

Serum was separated from $5 \mathrm{ml}$ of patient and normal subjects' blood, and total serum IgE levels were measured using the ELISA kit (Genesis Diagnostics, UK) according to the manufacturer's instructions.

\section{DNA preparation}

Genomic DNA was extracted from peripheral blood using a DNG ${ }^{\text {lus }}$ extractor WB kit (Cinagen, Iran) according to the manufacturer's instructions.

\section{Determination of TLR2 Arg753Gln and TLR4 Asp299Gly gene polymorphisms}

Polymerase chain reaction-restriction fragment length polymorphism (PCR-RFLP) method was used for evaluation of TLR2 Arg753Gln, and TLR4 Asp299Gly polymorphism. PCR steps were performed using a thermal cycler (Techne, Genius, UK). PCR conditions, PCR cycles and primers (FERMENTAS Inc, 830 Harrington Court,Burlington Ontario, Canada) are summarized in Tables $\mathbf{2}$ and $\mathbf{3}$. In brief, PCR materials were mixed according to Tables $\mathbf{2}$ and $\mathbf{3}$ and tubes passed thermal cycles as summarized in Table 2. After conformation of single bands of $P C R$ product in agarose electrophoresis, restriction enzymes were affected. In a final volume of $25 \mu \mathrm{l} \mathrm{PCR}$ products were digested by Msp1 and Nco1 (Fermentas thermo scientific,

Table 2. PCR materials and cycles.

\begin{tabular}{l|l}
\hline Locus & PCR conditions \\
\hline TLR2 & $\begin{array}{l}35 \text { cycle: } 94^{\circ} \mathrm{C} 30 \mathrm{~s}, 58^{\circ} \mathrm{C} 50 \mathrm{~s}, 72^{\circ} \mathrm{C} 40 \mathrm{~s} \\
\end{array}$ \\
\hline TLR4 & 35 cycle: $94^{\circ} \mathrm{C} 20 \mathrm{~s}, 61^{\circ} \mathrm{C} 50 \mathrm{~s}, 72^{\circ} \mathrm{C} 50 \mathrm{~s}$ \\
& $50 \mathrm{ng}$ DNA, $200 \mu \mathrm{mol} \mathrm{dNTPs}, 2 \mathrm{mM} \mathrm{MgCl}_{2}$ \\
\hline
\end{tabular}

Table 3. Cytokine and internal control for PCR-RFLP primers.

\begin{tabular}{l|ll}
\hline Locus & Primers & Method \\
\hline TLR2 & $\begin{array}{l}\text { Forward: 5' TAAACTTGGGAGAACAT- } \\
\text { GGT -3' }\end{array}$ & Msp1 based RFLP \\
& $\begin{array}{l}\text { Reverse: 5' - TGGGGAAAGATAGAG- } \\
\text { TAATA -3' }\end{array}$ & \\
\hline TLR4 & $\begin{array}{l}\text { Forward: 5' - ACACAACTGTGTTCAC- } \\
\text { TAGC -3' } \\
\end{array}$ & $\begin{array}{l}\text { Reverse: 5' - CAACTTCATCCACGTT- } \\
\text { CACC -3' }\end{array}$ \\
\hline
\end{tabular}


Bahrami et al. HOAJ Biology 2014,

USA) restriction enzymes on TLR2 and TLR4 products, respectively and then digestions were monitored by agarose gel electrophoresis and ethidium bromide staining.

\section{Statistical analysis}

Allele and genotype frequencies were calculated in patient and control subjects by direct gene counting. Statistical evaluation was carried out using the Statistical package for the Social sciences (SPSS) version 15. The statistical significance of the difference was tested by $a x^{2}$ analysis with one difference or by the two-tailed Fisher's exact test when the criteria for the $x^{2}$ analysis were not fulfilled. The associations between genotypes and risk of asthma were estimated by computing the odds ratio (OR) and its $95 \%$ confidence interval $(\mathrm{Cl})$. For analysis of $\mathrm{lgE}$ and respiratory factors, differences in various gene variants the one way analysis variance test (ANOVA) and t-test were used. P-Values $<0.05$ were considered statistically significant. An exact test was used to evaluate deviations from expected Hardy-Weinberg genotypic proportions.

\section{Results}

The results of TLR2 Arg753Gln, and TLR4 Asp299Gly gene polymorphisms in asthmatic and normal subjects (Table 4), two levels of asthma controls (Table 5), sex, allergy history and familial history of asthma (Table 6) and serum IgE and respiratory factors in asthma patients (Table 7) are shown. Our results analysis didn't show any statistically significant difference between TLR2 Arg753GIn and TLR4 Asp299Gly genotypes and alleles of asthmatics and normal subjects $(P>0.05)$. Other features of asthma as asthma control levels, serum IgE, history and pulmonary factors also were not different in TLR2 Arg753Gln and TLR4 Asp299Gly different variants $(P>0.05)$.

\section{Discussion}

Asthma is a multifactor chronic inflammatory disorder of the airways and a variety of genetic and environmental factors contribute to its pathogenesis. Immune and inflammatory elements are important factors in induction, progress and clinical outcomes of asthma [6]. Molecules and elements that are linker of environmental factors effects in these inflammatory responses and then their genetic background will be critical factors in asthma etiology or features. TLRs are pattern recognition receptors, are highly polymorphic, and play an important role in both innate and adaptive immunity $[9,16]$. TLR2 mainly responds to cell wall structure components from gram-positive bacteria, such as peptidoglycan, and TLR4 mainly recognizes microbial membrane components from gramnegative bacteria, such as lipopolysaccharide (LPS) or endotoxin $[9,17]$. TLRs polymorphisms may play role in the balance between Th1 and Th2 responses, and increased susceptibility to allergic airway diseases. In a study to quantify messenger RNA (mRNA) and protein expression of TLR2, TLR3, and TLR4 in the nasal mucosa of patients with seasonal allergic rhinitis before and after challenge with relevant pollens identified, protein expression for all three TLRs was demonstrated to increase in patients with rhinitis after challenge. This study raises the possibility that TLRs polymorphisms may have a role in the development of allergic airway inflammation [18]. TLR2 is encoded at 4q32 and TLR4 located at 9q32-33. TLR4 polymorphisms have been associated with reduced risk of allergic rhinitis, atopy, and airway responsiveness in several studies $[18,19]$ The reduced immune responses of TLR2 polymorphisms have also been investigated in experimental studies using human cells or animal models $[20,21]$. All of these data support TLRs molecules and also their polymorphisms roles in asthma features. With regard to these findings we evaluated two main polymorphisms as TLR2 Arg753Gln, and TLR4 Asp299Gly in Iranian asthmatic patients and then analyzed correlation of these variants with serum IgE levels, respiratory factors, patient's allergy and familial history and also standard control levels of asthma in these patients. Analysis of our results didn't show any positive correlation of TLR2 Arg753Gln, and TLR4 Asp299Gly polymorphisms with asthma risk, IgE levels, lung functions, control level or even familial allergy/asthma history. For explanation of these results we looked up at some

Table 4. Results of TLR2 Arg753Gln and TLR4 Asp299Gly SNPs determined in asthmatics and normal subjects.

\begin{tabular}{l|llllll}
\hline Gene & Genotype & $\begin{array}{l}\text { Asthma } \\
\text { \%(N) }\end{array}$ & $\begin{array}{l}\text { Normal } \\
\%(N)\end{array}$ & P value & OR & \%95CI \\
\hline TLR2 & GG & $\% 92.9(92)$ & $\% 94.2(113)$ & 0.709 & 0.814 & $0.276-2.405$ \\
& GA+AA & $\% 7.1(7)$ & $\% 5.8(7)$ & & & \\
& G allele & $\% 96.5(191)$ & $\% 97.1(233)$ & 0.714 & 0.820 & $0.283-2.378$ \\
& A allele & $\% 3.5(7)$ & $\% 2.9(7)$ & & & \\
\hline \multirow{2}{*}{ TLR4 } & AA & $\% 85.9(85)$ & $\% 86.7(104)$ & 0.863 & 0.934 & $0.431-2.022$ \\
& AG+GG & $\% 14.1(14)$ & $\% 13.3(16)$ & & & \\
& A allele & $\% 92.9(184)$ & $\% 93.3(224)$ & 0.868 & 0.939 & $0.446-1.974$ \\
& G allele & $\% 7.1(14)$ & $\% 6.7(16)$ & & & \\
\hline
\end{tabular}

$\mathrm{N}$, absolute number; CI: Confidence Interval; OR:Odds ratio 
Bahrami et al. HOAJ Biology 2014,

http://www.hoajonline.com/journals/pdf/2050-0874-3-1.pdf

doi: $10.7243 / 2050-0874-3-1$

Table 5. Results of TLR2 Arg753Gln and TLR4 Asp299Gly SNPs distribution in asthma control levels.

\begin{tabular}{l|llllll}
\hline Gene & Genotype & Controlled Asthma $\%(N)$ & Uncontrolled Asthma \%(N) & P value & OR & \%95CI \\
\hline TLR2 & GG & $\% 95.3(41)$ & $\% 91.1(51)$ & 0.411 & 2.010 & $0.371-10.898$ \\
& GA+AA & $\% 4.7(2)$ & $\% 8.9(5)$ & & & \\
& G allele & $\% 97.7(84)$ & $\% 95.5(107)$ & 0.419 & 1.963 & $0.371-10.369$ \\
& A allele & $\% 2.3(2)$ & $\% 4.5(5)$ & & & \\
\hline \multirow{2}{*}{ TLR4 } & AA & $\% 86.0(37)$ & $\% 85.7(48)$ & 0.962 & 1.028 & $0.328-3.220$ \\
& AG+GG & $\% 14.0(6)$ & $\% 14.3(8)$ & & & \\
& A allele & $\% 93.0(80)$ & $\% 92.9(104)$ & 0.964 & 1.026 & $0.342-3.075$ \\
& G allele & $\% 7.0(6)$ & $\% 7.1(8)$ & & & \\
\hline
\end{tabular}

$\mathrm{N}$, absolute number; CI: Confidence Interval; OR: Odds ratio

Table 6. Distribution and P values for TLR2 Arg753Gln and TLR4 Asp299Gly variants in sex, allergy history and familial history of asthma groups.

\begin{tabular}{l|l|lll|lll}
\hline \multirow{2}{*}{ Gene } & \multirow{2}{*}{ Genotype } & \multicolumn{3}{c|}{ Distribution (N) } & \multicolumn{3}{c}{ P value } \\
\cline { 3 - 8 } & & Sex M/F & Allergy P/N & History P/N & Sex & Allergy & History \\
\hline TLR2 & wwGG & $26 / 66$ & $63 / 29$ & $44 / 48$ & & & \\
& GA+AA & $2 / 5$ & $7 / 0$ & $3 / 4$ & 0.986 & 0.077 & 0.800 \\
& G allele & $54 / 137$ & $133 / 58$ & $91 / 100$ & & & \\
& A allele & $2 / 5$ & $7 / 0$ & $3 / 4$ & 0.986 & 0.077 & 0.803 \\
\hline TLR4 & AA & $25 / 60$ & $59 / 26$ & $39 / 46$ & & & \\
& AG+GG & $3 / 1$ & $11 / 3$ & $8 / 6$ & 0.539 & 0.485 & 0.434 \\
& A allele & $53 / 131$ & $129 / 55$ & $86 / 95$ & & & \\
& G allele & $3 / 11$ & $11 / 3$ & $8 / 6$ & 0.555 & 0.502 & 0.452 \\
\hline
\end{tabular}

M: Male; F: Female; P: Positive; N: Negative

Table 7. IgE concentrations and P values for association between TLR2 Arg753Gln and TLR4 Asp299Gly polymorphisms and serum IgE and respiratory factors of asthma patients.

\begin{tabular}{|c|c|c|c|c|c|c|c|c|c|}
\hline \multirow[t]{2}{*}{ Gene } & \multirow[t]{2}{*}{ Genotype } & \multirow[t]{2}{*}{ IgE Cons. (IU/ml) } & \multicolumn{7}{|c|}{ P value } \\
\hline & & & IgE & Age & FEV1 (\%P) & FVC (\%P) & FEV1/FVC (\%P) & FEF $25-75 \%(\% P)$ & PEF (\%P) \\
\hline \multirow[t]{4}{*}{ TLR-2 } & GG & $113.84 \pm 251.38$ & & & & & & & \\
\hline & $\mathrm{GA}+\mathrm{AA}$ & $241.61 \pm 564.32$ & 0.258 & 0.658 & 0.928 & 0.731 & 0.663 & 0.282 & 0.436 \\
\hline & G allele & $119.16 \pm 268.71$ & & & & & & & \\
\hline & A allele & $241.61 \pm 564.32$ & 0.265 & 0.662 & 0.929 & 0.733 & 0.256 & 0.665 & 0.440 \\
\hline \multirow[t]{4}{*}{ TLR-4 } & $\mathrm{AA}$ & $117.37 \pm 257.65$ & & & & & & & \\
\hline & $\mathrm{AG}+\mathrm{GG}$ & $116.20 \pm 433.55$ & 0.584 & 0.371 & 0.158 & 0.295 & 0.948 & 0.427 & 0.238 \\
\hline & A allele & $120.94 \pm 271.91$ & & & & & & & \\
\hline & G allele & $166.20 \pm 433.55$ & 0.596 & 0.388 & 0.174 & 0.315 & 0.949 & 0.440 & 0.257 \\
\hline
\end{tabular}

Forced Expiratory Volume in 1 Second, FVC: Forced Vital Capacity; PEF: Peak Expiratory Flow; FEF25-75: Forced Expiratory Flow $25-75 \%$

previous studies. A study on Chinese asthmatics analyzed four SNP in TLR4 gene resulted polymorphisms in TLR4 gene are associated with asthma severity but not susceptibility [22]. These researchers in another paper on the same patients reported positive correlation TLR2/rs7656411 TT variant and risk of asthma [23]. In a study single nucleotide polymorphisms (SNPs) in the TLR2 (4 SNPs) and TLR4 genes (9 SNPs) were genotyped in asthmatic children. In these subjects Two TLR2 SNPs and four TLR4 SNPs significantly modified the effect of air pollution on the prevalence of doctor-diagnosed asthma [24]. A study reported protective effects of TLR2-16933T/A polymorphisms on lung function among workers in swine operations while in these subjects there were no significant differences between Asp299Gly and Thr399lle polymorphisms 
Bahrami et al. HOAJ Biology 2014,

in the TLR4 gene and lung function values [25]. In another study on Danish asthmatic farmers three CD14 SNPs, three TLR2 SNPs (-16934 A/T, Pro631His C/A and Arg753Gln C/T), and two TLR4 SNPs (Asp299Gly A/G and Thr399lle C/T) were evaluated and their results indicated no associations between CD14, TLR2, or TLR4 genotypes and new-onset asthma [26]. In a quick look to the previous studies and with attention to probable role of TLRs in asthma we see several studies that have mentioned polymorphisms or other SNPs in TLR2 and TLR4 genes are involved in asthma and meanwhile there are also several studies that have showed no such association. These controversies may be due to several explanation such as: genetic complexity and/or nature of asthma pathogenesis and pathophysiology with involvement of various factors including genetic and environmental factors, ethnicity and different genetic background of studied subjects, overcame of other molecules and their genetic variations on TLRs functions and even effectiveness of other polymorphisms in TLR2 and TLR4 genes more than two TLR2 Arg753Gln and TLR4 Asp299Gly studied polymorphisms in Iranian asthmatic patients. We would mention that in previous study in almost the same asthmatics, we showed effectiveness of cytokine polymorphism in asthma susceptibility and its features in Iranian asthmatic patients [27].

\section{Conclusion}

In this study denyed to indicate TLR2 Arg753GIn and TLR4 Asp299Gly polymorphisms as a risk factor for asthma in Iranian patients. These studies SNPs also didn't affect asthma features as IgE levels, lung functions, control level or even familial allergy/asthma history. With regard to positive correlations in some of other studies and supposed roles of TLR2 and TLR4 in modification of immune and inflammatory responses further studies on other SNPs or other involved may be beneficial for clarification of controversies in multifactor asthma disease.

\section{Competing interests}

The authors declare that they have no competing interests.

Authors' contributions

\begin{tabular}{|l|c|c|c|c|}
\hline Authors' contributions & HB & SD & HH & AP \\
\hline Research concept and design & $\checkmark$ & -- & -- & $\checkmark$ \\
\hline Collection and/or assembly of data & $\checkmark$ & -- & -- & $\checkmark$ \\
\hline Data analysis and interpretation & $\checkmark$ & -- & -- & $\checkmark$ \\
\hline Writing the article & $\checkmark$ & -- & -- & $\checkmark$ \\
\hline Critical revision of the article & $\checkmark$ & -- & -- & $\checkmark$ \\
\hline Final approval of article & $\checkmark$ & $\checkmark$ & $\checkmark$ & $\checkmark$ \\
\hline Statistical analysis & $\checkmark$ & -- & -- & $\checkmark$ \\
\hline
\end{tabular}

\section{Acknowledgement}

The authors are grateful to the Department of Immunology of Tarbiat Modares University for financial support.

Publication history

EIC: Eduardo Spinedi, La Plata University, Argentina. Received: 18-Apr-2014 Final Revised: 16-Jul-2014

Accepted: 04-Aug-2014 Published: 02-Sep-2014

\section{References}

1. Basehore MJ, Howard TD, Lange LA, Moore WC, Hawkins GA, Marshik PL, Harkins MS, Meyers DA and Bleecker ER. A comprehensive evaluation of IL4 variants in ethnically diverse populations: association of total serum IgE levels and asthma in white subjects. J Allergy Clin Immunol. 2004; 114:80-7. | Article | PubMed

2. Price $D$ and Thomas $M$. Breaking new ground: challenging existing asthma guidelines. BMC Pulm Med. 2006; 6 Suppl 1:S6. | Article | PubMed Abstract | PubMed Full Text

3. Georgy V, Fahim HI, El-Gaafary M and Walters S. Prevalence and socioeconomic associations of asthma and allergic rhinitis in northern [corrected] Africa. Eur Respir J. 2006; 28:756-62. | Article | PubMed

4. Aoki T, Hirota T, Tamari M, Ichikawa K, Takeda K, Arinami T, Shibasaki $\mathrm{M}$ and Noguchi E. An association between asthma and TNF-308G/A polymorphism: meta-analysis. J Hum Genet. 2006; 51:677-85. | Article I PubMed

5. Barnes PJ. The role of inflammation and anti-inflammatory medication in asthma. Respir Med. 2002; 96 Suppl A:S9-15. | Article | PubMed

6. Ngoc PL, Gold DR, Tzianabos AO, Weiss ST and Celedon JC. Cytokines, allergy, and asthma. Curr Opin Allergy Clin Immunol. 2005; 5:161-6. | Article | PubMed

7. Imler JL and Hoffmann JA. Toll receptors in innate immunity. Trends Cell Biol. 2001; 11:304-11. | Article | PubMed

8. O'Neill LA and Bowie AG. The family of five: TIR-domain-containing adaptors in Toll-like receptor signalling. Nat Rev Immunol. 2007; 7:35364. | Article | PubMed

9. Lien E, Sellati TJ, Yoshimura A, Flo TH, Rawadi G, Finberg RW, Carroll $J D$, Espevik T, Ingalls RR, Radolf JD and Golenbock DT. Toll-like receptor 2 functions as a pattern recognition receptor for diverse bacterial products. J Biol Chem. 1999; 274:33419-25. | Article | PubMed

10. Sun $D$, Yang $X$, Zhao $X$ and Liu E. [Alterations in intestinal microflora balance induce maturity and increase the expressions of TLR2 and TLR4 of dendritic cells in mouse lung]. Xi Bao Yu Fen Zi Mian Yi Xue Za Zhi. 2013; 29:923-6. | Article | PubMed

11. Sutmuller RP, den Brok MH, Kramer M, Bennink EJ, Toonen LW, Kullberg BJ, Joosten LA, Akira S, Netea MG and Adema GJ. Toll-like receptor 2 controls expansion and function of regulatory T cells. J Clin Invest. 2006; 116:485-94. | Article | PubMed Abstract | PubMed Full Text

12. Gao Z, Dosman JA, Rennie DC, Schwartz DA, Yang IV, Beach J and Senthilselvan A. Association of Toll-like receptor 2 gene polymorphisms with lung function in workers in swine operations. Ann Allergy Asthma Immunol. 2013; 110:44-50 e1. | Article | PubMed

13. Brandt EB, Gibson AM, Bass S, Rydyznski C and Khurana Hershey GK. Exacerbation of allergen-induced eczema in TLR4- and TRIF-deficient mice. J Immunol. 2013; 191:3519-25. | Article | PubMed

14. Global Strategy for Asthma Management and Prevention, Global Initiative for Asthma (GINA). 2006. I Website

15. American Thoracic Society. Standards for the diagnosis and care of patients with chronic obstructive pulmonary disease (COPD) and asthma. | Website

16. Kawai T and Akira S. The role of pattern-recognition receptors in innate immunity: update on Toll-like receptors. Nat Immunol. 2010; 11:373-84. | Article | PubMed

17. Fransson M, Adner M, Erjefalt J, Jansson L, Uddman R and Cardell LO. Upregulation of Toll-like receptors $\mathbf{2 , 3}$ and $\mathbf{4}$ in allergic rhinitis. Respir Res. 2005; 6:100. | Article | PubMed Abstract | PubMed Full Text

18. Schwartz DA. TLR4 and LPS hyporesponsiveness in humans. Int $J$ Hyg Environ Health. 2002; 205:221-7. | Article | PubMed

19. Senthilselvan A, Rennie D, Chenard L, Burch LH, Babiuk L, Schwartz DA and Dosman JA. Association of polymorphisms of toll-like receptor 4 with a reduced prevalence of hay fever and atopy. Ann Allergy Asthma Immunol. 2008; 100:463-8. | Article | PubMed

20. Yang HZ, Cui B, Liu HZ, Chen ZR, Yan HM, Hua F and Hu ZW. Targeting TLR2 attenuates pulmonary inflammation and fibrosis by reversion of suppressive immune microenvironment. J Immunol. 2009; 182:692-702. 
Bahrami et al. HOAJ Biology 2014,

http://www.hoajonline.com/journals/pdf/2050-0874-3-1.pdf

| Article | PubMed

21. Poole JA, Wyatt TA, Kielian T, Oldenburg P, Gleason AM, Bauer A, Golden G, West WW, Sisson JH and Romberger DJ. Toll-like receptor 2 regulates organic dust-induced airway inflammation. Am J Respir Cell Mol Biol. 2011; 45:711-9. | Article | PubMed Abstract | PubMed Full Text

22. Zhang Q, Qian FH, Zhou LF, Wei GZ, Jin GF, Bai JL and Yin KS.

Polymorphisms in toll-like receptor 4 gene are associated with asthma severity but not susceptibility in a Chinese Han population. J Investig Allergol Clin Immunol. 2011; 21:370-7. | Article | PubMed

23. Qian FH, Zhang Q, Zhou LF, Jin GF, Bai JL and Yin KS. Polymorphisms in the toll-like receptor 2 subfamily and risk of asthma: a case-control analysis in a Chinese population. J Investig Allergol Clin Immunol. 2010; 20:340-6. | Article | PubMed

24. Kerkhof M, Postma DS, Brunekreef B, Reijmerink NE, Wijga AH, de Jongste JC, Gehring $U$ and Koppelman GH. Toll-like receptor $\mathbf{2}$ and 4 genes influence susceptibility to adverse effects of traffic-related air pollution on childhood asthma. Thorax. 2010; 65:690-7. | Article | PubMed

25. Gao Z, Dosman JA, Rennie DC, Schwartz DA, Yang IV, Beach J and Senthilselvan A. Association of Toll-like receptor 2 gene polymorphisms with lung function in workers in swine operations. Ann Allergy Asthma Immunol. 2013; 110:44-50 e1. | Article | PubMed

26. Smit LA, Bongers SI, Ruven HJ, Rijkers GT, Wouters IM, Heederik D, Omland $\mathrm{O}$ and Sigsgaard T. Atopy and new-onset asthma in young Danish farmers and CD14, TLR2, and TLR4 genetic polymorphisms: a nested case-control study. Clin Exp Allergy. 2007; 37:1602-8. | Article | PubMed

27. Daneshmandi S, Pourfathollah AA, Pourpak Z, Heidarnazhad H and Kalvanagh PA. Cytokine gene polymorphism and asthma susceptibility, progress and control level. Mol Biol Rep. 2012; 39:1845-53. | Article | PubMed

\section{Citation:}

Bahrami H, Daneshmandi S, Heidarnazhad $\mathrm{H}$ and Pourfathollah AA. Lack of association between toll like receptor-2 \& toll like receptor-4 gene polymorphisms and Iranian asthmatics risk or features. HOAJ Biol. 2014; 3:1.

http://dx.doi.org/10.7243/2050-0874-3-1 